\title{
JG|U
}

Gutenberg School of Management and Economics

\& Research Unit "Interdisciplinary Public Policy"

Discussion Paper Series

\section{"Babies of the War:}

\section{The effect of war exposure early in life on mortality throughout life"}

Maarten Lindeboom and Reyn van Ewijk 2015

Discussion paper number 1519 
Contact details:

Maarten Lindeboom

VU University, Amsterdam

Department of Economics

De Boelelaan 1105, $1081 \mathrm{HV}$

Amsterdam, The Netherlands

\section{Reyn van Ewijk}

University of Mainz

Chair of Statistics and Econometrics

Jakob-Welder-Weg 4

55128 Mainz, Germany

vanewijk@uni-mainz.de 


\title{
Pre-publication version of the paper:
}

"Babies of the War:

\section{The effect of war exposure early in life on mortality throughout life" Published in "Biodemography and Social Biology"}

\author{
Maarten Lindeboom ${ }^{1}$ \\ Reyn van Ewijk ${ }^{2}$
}

Cite as: Lindeboom M, Van Ewijk R (2015). Babies of the War: The effect of war exposure early in life on mortality throughout life. Biodemography and Social Biology, 61(2): 167-186.

\begin{abstract}
There is increasing evidence that circumstances very early in our lives, and particularly during pregnancy, can affect our health for the remainder of life. Studies that have looked at this often used extreme situations such as famines that occurred during war times. Here we investigate whether less extreme situations during World War 2 also affected later life mortality for cohorts born in Belgium, France, The Netherlands and Norway. We argue that these occupied countries experienced a considerable deterioration in daily life situations and show that this resulted in strongly increased mortality rates and lower probabilities of survival until age 55 among civilian populations who had been prenatally exposed to war time circumstances. However, this mortality effect among the prenatally exposed is entirely concentrated in the first years of life, particularly infanthood. Once we condition on having survived the first years of life, those who had been prenatally exposed do not have higher mortality rates. This suggest that "culling" is important and that effects found in earlier studies may have been biased downward substantially.
\end{abstract}

\footnotetext{
${ }^{1}$ Department of Economics, VU University Amsterdam, The Netherlands

${ }^{2}$ Faculty of Law and Economics, Johannes Gutenberg-University Mainz, Germany
}

Address correspondence to Reyn van Ewijk, Jakob-Welder-Weg 4, D-55128 Mainz, Germany. E-mail: vanewijk[at]uni-mainz.de 


\section{Introduction}

Early-life circumstances, and particularly circumstances during pregnancy, can affect our health throughout all stages of our life course, as an increasingly large body of research has shown. Previous research predominantly focused on the effects of poor nutritional circumstances, pollution, substance abuse, stress, severe epidemics and economic crises during the gestational period. These prenatal conditions are shown to increase the risks of cardiovascular disease and its biological risk factors, such as hypertension and type 2 diabetes later in life; to lead to poorer human capital outcomes (education, wages, cognitive performance); and to increase the risks of developing mental health problems later in life. And many of these effects get stronger as the prenatally exposed get older (Almond \& Currie, 2011; Lumey et al., 2011).

Research in this domain is usually driven by fetal programming (also known as "fetal origins") theory. This theory explains how poor adverse circumstances during pregnancy cause damage to the fetal body that does not need to lead to immediate health problems. It is hypothesized that fetal adaptations tend to occur in such a way that immediate survival chances are optimized, for example since scarce nutrients are predominantly channeled toward the most vital organs. But this may go at the expense of other organs, where cell division is slowed. The resulting damage often does not create immediate health problems, but leads to problems only later in life, as degeneration sustained during the lifetime has taken its own toll. Fetal programming theory thus predicts direct effects on later-life outcomes. But indirect mechanisms may also play a role, i.e. poor prenatal conditions may lead to reduced child health, which subsequently leads to poorer health at later life stages (Kuh \& Ben-Shlomo, 2004).

There now exists a considerable amount of literature that tests whether there exists a causal relationship between early life conditions and later life health and mortality. Such studies nowadays typically rely on exogenous variation in early life conditions implied by aggregated events, rather than using proxies of the individual environment such as birth weight (see e.g. Davey Smith (2005) for an overview). The idea is that proxies of the individual environment may be confounded by unobserved biological or social factors. Aggregate events can be used if it is likely that these affect the individual environment but that they do not directly affect later life health, other than via the conditions in early childhood. There is an extensive literature that has used famines induced by wars as aggregate events (See e.g. Roseboom et al. (2011) for an overview see Vaiserman \& Lumey (2013). However, famines, typically constituted very specific and rather extreme circumstances that differed from the conditions that were experienced by the great majority of European populations during most of World War 2 (WW2).

We argue that wars, and WW2 in particular, is a relevant exposure beyond this. Most of the people experiencing war-like circumstances were civilians who were not affected by famines and in 
most cases were not directly affected by combat actions. Still, war affected them considerably, since food was rationed, leading to poor nutrition both in terms of quantity and quality; since stress levels tended to be high due to occupation and the risks of persecution, bombings or combat; since WW2 was accompanied by a severe economic downturn; and since health care systems functioned below normal standards.

We focus on the effects on health throughout the life course of prenatal exposure to the adverse circumstances that were experienced by most European civilian populations during most of WW2. We know from previous literature that negative health effects of prenatal exposure occur under circumstances that are much less extreme than famines. The conditions faced by the civilian populations of many European countries during WW2 seem adverse enough to expect negative effects on later-life health, but virtually nothing is known yet about the existence and size of such effects. ${ }^{1}$ Further investigating the effects of wars is also relevant for interpreting results from earlier research in this area that used more extreme events such as famines. These studies typically look at cohorts alive at a certain point in time and relate their current health to cohort circumstances early in life. If we find that adverse prenatal circumstances increase mortality rates, then analyses on other health outcomes may have been biased downwards due to selective mortality, also referred to as culling in the literature.

In this paper, we focus on four countries where the civilian population has been exposed to adverse circumstances such as poor nutrition without famine-like circumstances, stress, economic crises, and potentially sub optimal health care systems during the course of WW2: Belgium, France, The Netherlands and Norway. These countries faced similar conditions, which makes them suitable for the purpose of this paper. Each of these countries was occupied from spring 1940 on and was liberated (depending on the region within the country) between June 1944 and May 1945 and had no major border changes after the war. This facilitates the comparability of the cohorts included in this study. The Netherlands faced a famine at the end of the war (the Dutch Hunger winter), but we will control for this by allowing for year specific effects in our analyses. ${ }^{2}$

We excluded countries with major border changes and further limited our choice to countries for which data were available from the Human Mortality Database (HMD) on the cohorts that we focus on. No data were available on Eastern European countries. The axis countries were excluded, partially due to unavailability of HMD-data (Germany, Austria) and major border changes, and partially because

\footnotetext{
${ }^{1}$ One of the very few other WW2-studies that did not focus on famines is Van Os \& Selten (1998). They focused on increased stress levels during the May 1940 German invasion in The Netherlands and showed that prenatal exposure increases the chances that the offspring will develop schizophrenia. There is, to our knowledge, no literature that studies similar types of effects by focusing on other wars.

${ }^{2}$ Denmark is excluded, since circumstances were less adverse during much of the war. Denmark remained a functioning democracy and conditions (including rations (Egle, 1943)) remained relatively favorable until mid1943 , when the government was dissolved and martial law instituted by the occupiers.
} 
in the remaining available axis country, Italy, the periods of exposure to non-extreme war-time situations are less clearly defined. During the earlier war years in Italy, there was no occupation-related stress and food rations tended to be more generous than in the occupied countries; during later years, there was an allied occupation in part of the country and a civilian war. Furthermore, countries in which other wars were fought around the same time period were excluded (Spain, Finland), since this would have necessitated a change in focus away from WW2. The United Kingdom was excluded, since it was neither neutral, nor occupied, so that the nature and extent of exposure differs considerably from the other countries.

We contrast Belgium, France, The Netherlands and Norway with two other developed countries in this period that were neutral in the war, Sweden and Switzerland. These countries are geographically and culturally close to the occupied countries that we study, with the difference that they were not exposed to war in the same period. We include analyses on these neutral countries to ensure that any effects that we may find among the occupied countries are not due to non-war-related contemporaneous circumstances that would also have affected unoccupied countries. Most important among these circumstances are fertility patterns: in all countries (occupied and unoccupied), fertility rates were declining before the war and there was a post-war baby-boom. If being born during WW2 were associated with health throughout the life course in Sweden and Switzerland, then this association would likely not be due to the war per se, but rather to cohort effects, e.g. since parents conceiving during the baby boom may have systematically differed from parents conceiving in earlier years. Another example of non-war-related contemporaneous circumstances that may have had longterm effects are epidemics (cf. the Spanish flu during the First World War (Almond \& Mazumder, 2005)).

\section{Mechanisms linking wartime early life conditions to later life health.}

Most people experiencing war-like circumstances are civilians who are not affected by combat actions and in most cases not by famines. Still, war will have an impact on individual lives since food is often rationed, leading to poor nutrition both in terms of quantity and quality. Stress levels arguably tended to be high due to occupation and the risk of persecution, bombings or combat. Further, WW2 was accompanied by a severe economic downturn and during time of war health care systems functioned below normal standards. Below we expand on how each of these factors may alter the intrauterine environment.

\section{Prenatal exposure to poor nutrition}

Poor nutrition during pregnancy is by far the most studied prenatal exposure. Most studies to date focused on famines; others looked at effects of less extreme exposures such as skipping meals 
(particularly breakfast) and Ramadan fasting during pregnancy. The effects of all these types of poor nutrition are theorized to be caused by the same biological processes. The explanation for this is that the bodies of women who skip meals during pregnancy relatively quickly reach states, characterized by low serum levels of glucose and alanine, and especially high levels of free fatty acids, that are otherwise only seen in starvation (Metzger et al., 1982). This "accelerated starvation" has been shown to occur both when women skip meals such as breakfast, and when women fast during the Islamic month of Ramadan (Alwasel et al. 2010; Malhotra et al., 1989; Mirghani et al., 2004, 2005; Prentice et al., 1983).

When there is a lack of nutrition, the fetus will adapt by using most of the scarce energy for the most vital organs (particularly the brain), in order to protect these against the lack of fuel (Godfrey \& Barker, 2001). This occurs at the expense of energy devoted to other organs, muscles and limbs. As a consequence, cell division in these other body parts is slowed. This affects fetal growth in general and especially the development of organs undergoing their critical growth period: the period during which they are formed or go through an important growth phase. Even short periods of under nutrition can cause damage to these organs (Barker, 1997). And this damage may only lead to health problems much later during the lifetime.

The literature on poor nutrition during pregnancy is relevant to World War 2, since in all occupied countries food was rationed. For example, the average daily rations amounted to 1180 calories for France, 1400 for Belgium and 1800 for The Netherlands (Mouré, 2010). This is around half of the recommended number of calories per day for pregnant women. Furthermore, the quality of nutrition decreased as several types of food became rationed (see Egle, 1943).

Prenatal exposure to poor nutrition has been linked to a large number of negative health effects in later life. Most importantly, it has been shown to lead to increased incidences of coronary heart disease and non-insulin dependent diabetes, raised blood pressures, increased ratios of lowdensity to high-density lipoproteins (LDL/HDL ratio), increased incidences of obstructive airways disease and higher disability rates, as well as changes in body mass index (Almond \& Mazumder, 2011; Barker, 1995; Barker et al., 1989; Chen \& Zhou, 2007; Lopuhaä et al., 2000; Meng \& Qian, 2009; Roseboom et al. 2000a; Roseboom et al., 2000b; Van Ewijk, 2011; Van Ewijk et al., 2013). Furthermore, prenatal exposure is shown to lead to decreases in cognitive performance that last throughout life, to negatively affect labor market outcomes and to increase the risk of developing schizophrenia (Almond, Mazumder \& Van Ewijk, 2014; De Rooij et al., 2010; Scholte et al., 2012; St. Clair et al., 2005). Finally, mortality rates among elderly people are higher among people who had been prenatally exposed to a famine (Lindeboom et al., 2010). 
High levels of the stress hormone $\mathrm{CRH}$ (corticotropin-releasing hormone) are thought to prepare the fetus for an expected preterm delivery. It results in a speeding up of tissue maturation, but a reduction in fetal growth (Hermann et al., 2001; Hobel \& Culhane, 2003). Importantly, prenatal exposure to stress hormones may increase the responsiveness of the HPA-axis (hypothalamic-pituitary-adrenal axis: a system that controls much of the human hormonal system, including reactions to stress). This results in an increased propensity to develop stress-related symptoms such as hypertension, as well as type 2 diabetes in adulthood (Kapoor et al., 2006; Seckl \& Holmes, 2007). Moreover, as stress during pregnancy is thought to affect neurological development, it can lead to cognitive, emotional and behavioral problems, as well as to higher incidences of schizophrenia among the offspring (Cotter \& Pariante, 2002; Van den Bergh et al., 2005; Van Os \& Selten, 1998).

The literature on stress during pregnancy is relevant to World War 2 since stress levels were likely to be elevated due to occupation, repression, persecution, the risk of being directly affected by bombings and fighting, and the risks that one knew that family members and friends faced. For example, Van Os \& Selten (1998) study effects of prenatal exposure to maternal stress utilizing the increased stress levels faced by the Dutch population during the 1940 German invasion. It should be noted that poor nutrition can also lead to stress, so that effects of prenatal exposure to poor nutrition and prenatal exposure to stress are generally hard to disentangle.

\section{Prenatal exposure to economic crises}

The literature on long-term effects of early life exposure to recessions usually treats economic crises as a proxy for poor general circumstances, which includes high levels of stress, poor nutrition and diseases. Yeung et al. (2014) and Van den Berg et al. (2011) showed that early-life exposure to economic crises in the late $19^{\text {th }}$ and early $20^{\text {th }}$ centuries increased later-life mortality rates and Banerjee et al. (2010) found that exposure decreased height. Other studies, however, found no effects of economic downturns on health outcomes at old age (Cutler et al., 2007; Lindeboom \& Van Ewijk, 2013). And one study even found that nowadays, the health of newborns is better in recessions (Dehejia \& Lleras-Muney, 2004). These mixed results might be due to the fact that biological exposure processes differ between recessions and change over time. For example, in earlier times, malnutrition, stress and epidemics might have been the most relevant aspects of economic crises. Nowadays, the fact that recessions reduce the opportunity costs of time, so that parental health behaviors improve, may be more relevant (Dehejia \& Lleras-Muney, 2004). The literature on prenatal exposure to economic crises is relevant for this paper since WW2 led to a severe economic contraction throughout the affected countries. 
Health care systems may function sub-optimally in times of war. The availability and delivery of medical goods may be sub-standard. For instance, due to a diversion of resources from the occupied country to the country of the occupier, fewer drugs, other medical supplies and staff may be available in the occupied country. The staffing of hospitals may also be affected by the persecution of ethnic and/or social groups. Over and above this, the adverse conditions during war times may also lead to a higher demand for care. All in all this may lead to worse treatment of those in need of care, including pregnant women.

\section{Data}

The data used in this research are from the Human Mortality Database (HMD). The HMD contains population-level birth and mortality data for a number of countries. The HMD data that we use are aggregated by sex, cohort (year of birth) and age. Our analyses consist of two stages. We start by showing that WW2 indeed had a 'bite', i.e. that it was a relevant exposure that affected daily life in such a way that it may have long term effects, even after excluding extreme circumstances such as the previously studied Dutch famine period. Next, we investigate the long-run effects of this early-life exposure.

\section{Deterioration of civilian health circumstances during World War 2}

To demonstrate that daily life circumstances during WW2 were so adverse that fetal-programming type effects were likely to have occurred, we look at trends over time in female life expectancy at birth. Life expectancy at birth for a particular year indicates how old someone born in that year would be expected to get if the mortality patterns at the time of her birth remained the same throughout her entire life. Thus, female life expectancy at birth summarizes the prevailing mortality rates of women of all ages at a particular moment in time. We focus on female life expectancy at birth, since male life expectancy is more strongly related to military actions and is therefore less informative on the circumstances that were experienced by the majority of the civilian population. Also, we are interested in effects of exposure to these circumstances in utero and females are the ones who are pregnant. Reductions from the trend in female life expectancy at birth can be interpreted as deterioration in the general health circumstances experienced by the civilian population.

For each country, we run an ordinary least squares regression of female life expectancy at birth on a linear term indicating birth year and dummies for each of the years 1940-1947. Each data point in this analysis is the life expectancy at birth of the entire population of females in one country in one particular year. In this analysis we included all cohorts born in the period running from 20 years before till 20 years after WW2, i.e. 1920-1965, in order to ensure that we capture the long-term time trend during the era in which WW2 fell. We capture this time trend using a linear polynomial for each 
country, but we also examined regressions using a quadratic in birth year and the results are similar. Taking a quadratic instead of a linear trend leads to a decrease in adjusted $\mathrm{R}^{2}$ in half of the countries. The linear time trend explained about $98 \%$ of variance in each country, so we are confident that it captures the prevailing time trend very well.

The dummy covariates for the years 1940-1945 provide estimates of the deviation from the trend in life expectancy during each of the war years. It is important that we allow the effects to differ between years, since they might otherwise be dominated by extreme circumstances that only existed during parts of the war. Specifically, a single estimate for a deviation from trend during the entire war period for The Netherlands would include the Dutch famine, whereas we are particularly interested in less extreme wartime exposures. Notice that we also include dummy variables for the years 1946 and 1947. This effectively sets these years apart and excludes them from the calculation of the long-term time trend. We do this because life expectancy at birth during these two years may still have been suppressed due to continued rationing of food and the effects of large flows of refugees. Furthermore note that the dummy for 1940 refers to the situation during this entire year, although the first months of 1940 were actually peacetime months. Assuming that circumstances during the first months of 1940 were not yet particularly adverse, we will therefore underestimate the effect of the 1940 wartime situation on life expectancy. A similar argumentation applies to the final war year.

The results from these analyses are presented in Table 1 and Figure 1. The figures show the time trend per country - calculated on data that exclude the years 1940-1947 - as well as the actual data. In all occupied countries, there are drops in female life expectancy at birth that last throughout the entire war period. In each of the countries, the drops are strongest towards the end of the war. The drops are notably smaller in Norway than in the other three countries. The most extreme drop is found for France In 1944, the year in which most of it was liberated: a 12 year reduction in life expectancy. But notably, in each of the countries, there are also substantial drops in life expectancy in 1941-1943: years that were not characterized by massive combat or famines. ${ }^{3}$

In the next step of this analysis, we try to ensure that these drops are not due to contemporaneous circumstances that are unrelated to the war and that also affected unoccupied countries. We therefore take data from Sweden and Switzerland and run the same regressions as we ran for the occupied countries. If we should find similar drops in female life expectancy at birth in these two countries during the WW2 period, then this would suggest that at least part of the pattern that we found for the occupied countries was not war-related. As Figure 1 and Table 1 show, there are no unexpected deviations from the trend in female life expectancy at birth in the two neutral countries.

\footnotetext{
${ }^{3}$ Note that the drops in female life expectancy are not mainly due to the holocaust. This is clearest when comparing France and The Netherlands: calculated as a share of the total population, around six times more Jews were murdered in The Netherlands than in France; yet France experienced a sharper drop in life expectancy than The Netherlands.
} 
This strengthens our confidence that the life expectancy pattern for the occupied countries is indeed due to war-related causes.

\section{Long-term effects of prenatal exposure to WW2}

After having established that circumstances of WW2 other than battles and famines are a relevant exposure in terms of deteriorated civilian health circumstances, we now turn to our main research question on the long-run effects of this early-life exposure. Based on fetal programming theory, we would expect higher mortality rates among the prenatally exposed. For each of the cohorts in the data, we calculate the probability that a male/female born in a particular country in this particular year survives until age 55 . Note that focusing on survival to later ages is not possible using HMD data: for survival up to age 55, we have cohort data available to 1953 for Belgium, The Netherlands and Norway, 1954 for France and 1955 for Sweden and Switzerland. This leaves us with a substantial post-war period, which we need for determining time trends. If we examined survival to age 60 , there would have been too few post-war years to reliably determine time trends (the last available cohorts would have been born in 1948 in Belgium, The Netherlands and Norway and 1949 in France). As in the previous analyses, we include cohorts born in 1920 or later.

We run a separate ordinary least squares regression for each combination of country and sex of the probability of surviving till age 55 on birth year and birth year squared and dummies for each of the years 1938-1947. Each observation in these regressions refers to the entire population of females/males born in one particular year in one particular country. In contrast to the previous set of analyses, we here include birth year squared since this considerably improves the model fit. The regressions again include dummy variables for the years 1946 and 1947, since the circumstances in these years were arguably different from those in the years that were more clearly unaffected by WW2. This is also substantiated by the results in Table 1, which demonstrated that female life expectancy at birth in 1946 was still below the long-term trend in the occupied countries.

We now also set apart, using dummy covariates, the years 1938 and 1939. These were pre-war years, but people born in these cohorts in the occupied countries were exposed to war-related adverse conditions very early in their lives, which may have had effects on their long-term health. Specifically, mortality rates are generally higher in the earliest years of infanthood, so that the exposure to adverse conditions that started in 1940 may have considerably affected mortality patterns of these two cohorts.

It is important to note that we focus on exposure during birth year. Obviously, people born before WW2 were also exposed to WW2-circumstances; not during early life, but during their childhood or youth. From a theoretical perspective, there is a strong expectation that effects are largest for exposure during the earliest stages of life. This why we set apart the 1938 and 1939 birth 
cohorts. But of course, the cohorts 1920-1937 suffered from WW2 as well. In our analyses, we investigate whether the WW2-born cohorts exhibit deviations from a trend that is partially based on the cohorts 1920-1937. If this is the case, this means that the effects of early-life exposure are larger than the effects of exposure during later stages of childhood or youth. If we find no such deviations, this may mean that the effect of early-life exposure is no larger than the effect of exposure during later stages of childhood or youth. This would be in conflict with the Barker hypothesis.

Furthermore, someone born in 1942 would also have been exposed postnatally in 1943-45, etc. Potential effects of exposure during early postnatal periods is hence part of our treatment for all war cohorts, although the final war year may be seen as an exception to this.

Figures 2 (for females) and 5 (for males) graphically show the results from the analyses. In Tables 2 and 3, the left column for each country gives the corresponding regression coefficients. The probability of reaching age 55 is lower than what would be expected based on long-term trends for people born in each of the war years in each of the occupied countries-notably also in the years that were not characterized by combat or famine. ${ }^{4}$ The probability to survive till age 55 is also lower than expected among those born shortly before the war, which indicates that effects cannot be attributed only to prenatal circumstances, but also to circumstances during infanthood. In France, The Netherlands and Norway, the probability of surviving till age 55 is also lower than expected among those born shortly after the war, which again confirms that circumstances had not immediately gotten back to normal..$^{5}$

In neutral Sweden, no similar pattern of results is found, which confirms that the reported effects for the occupied countries are not due to contemporaneous non-war-related circumstances. In Switzerland, there is also no clear effect pattern for males, although for females, there does seem to be a trend towards a reduced survival probability. This trend is clearly less strong than for the occupied countries. Perhaps circumstances in Switzerland during WW2 were adverse in some respects, due to its being completely surrounded by countries that were involved in the war. Recall, though, that this pattern did not show up in the analyses on female life expectancy at birth.

\section{Immediate vs long-term effects}

The effects reported in the previous paragraph may be either due to long-term reductions in health, as predicted by fetal programming theory, or simply to immediate effects. Perhaps some newborns did not survive the adverse circumstances that prevailed at the time. If so, this would not be a fetal programming-induced type of effect. This may particularly of concern, since infant mortality rates were

\footnotetext{
${ }^{4}$ Only for Norwegian males, these effects do not reach significance, which fits to the smaller deterioration in civilian life circumstances that is evidenced in Figure 1.

${ }^{5}$ Note that the dummies for 1940 and 1945 also cover people who were born before / after the war.
} 
relatively high in the era, even in the absence of war. The share of infants dying before age 1 among those born in 1938 was $8.6 \%$ in Belgium, $7.4 \%$ in France and 3.6\% in The Netherlands and Norway. Thus, the entire effect presented above might be due to immediate effects. To investigate whether this is indeed the case, or whether the reduced survival rates are due to fetal programming-type effects, we conduct the same regressions as before, but this time limit the sample to those who survived till at least age 1 (i.e. condition on survival upon age 1).

In a next step, we condition on having survived till at least age 5 . Under 5 mortality rates were still high during the era. E.g. of those who were born in 1934 (and who were thus not affected by WW2 in their first five life years) and who survived their first life year, 2.5\% died before reaching age 5 in Belgium; $2.6 \%$ in France, $1.4 \%$ in The Netherlands and $1.7 \%$ in Norway. If adverse circumstances during WW2 led to decreased health among infants, this may translate into higher mortality rates throughout the first phase of life. E.g. wartime malnutrition among infants may increase mortality immediately as well as a few years later. And congenital anomalies that were insufficiently treated due to a lack of medical infrastructure may also lead to increased mortality rates somewhat later. Both are not instances of fetal-programming. If we found that the probability of surviving until age 55 is decreased among the prenatally exposed, even if we look only at people who survived till at least age 5 , then it is likely that the effect is related to mechanisms such as those hypothesized in fetal programming theory.

Figures 3 (for females) and 6 (for males) show the results from these analyses that condition on surviving until age 1, and Figures 4 (for females) and 7 (for males) show the same for conditioning on survival until age 5 . Table 2 shows all corresponding parameter estimates. We find that the effects considerably decrease in size when we condition on reaching age 1 and completely disappear when we condition on reaching age 5. Apparently, the entire decrease in survival till age 55 among the prenatally exposed from the occupied countries is due to immediate increases in infant mortality and not to long-term health effects.

\section{Conclusion}

During World War 2, the occupied countries experienced considerable deteriorations in daily life situations. This resulted in strongly increased mortality rates among the civilian populations and lower probabilities of survival until age 55 among those who had been prenatally exposed to this period. However, this mortality effect among the prenatally exposed is entirely concentrated in the very first years of life and particularly infanthood. Once we condition on having survived the first years of life, those who had been prenatally exposed do not have higher mortality rates anymore.

This does not automatically conflict with the Barker hypothesis which predicts higher mortality rates in later life stages as well. Here we focus on mortality before age 55 , but much of the mortality from diseases that are associated with the Barker hypothesis (chronic degenerative diseases, and in 
particular cardiovascular diseases) occurs only at later ages. Indeed, despite the proven array of adverse long-term health effects of prenatal famine exposure, previous research on the Dutch famine found no effects on the probability of dying before age 57 (Painter et al., 2008), nor did research on the Chinese 1959-1961 Great Leap Forward famine find effects on mortality through age 35 (Song, 2009). Moreover, we cannot refute the hypothesis that early-life exposures in general have no effects on later-life mortality despite their proven effects on various intermediate outcomes. E.g. Cohen et al. (2010) found no late-life mortality effects of early-life exposure to the Spanish flu and Myrskylä (2010) shows that shocks that increase infant mortality have no effect on mortality after age 30.

Our results do however suggest that "culling" is important, i.e. among cohorts of prenatally exposed people, some of those with the worst health will be "missing", as the exposure led them to die during infanthood. This means that effects found in earlier studies on long-term effects of prenatal exposures may have been biased downward substantially. This is remarkable as the war years that we consider here are less extreme than famine year(s) used in epidemiological and economic studies (see for instance the Dutch hunger winter studies surveyed in Rooseboom et al, 2011, The Greek famine, Neelsen \& Stratman, 2011, and Jurges, 2011).

\section{Acknowledgments}

We thank participants at the conference on "Long-Run Impacts of Early Life Events IV: Evidence from Developed and Developing Economics" held at the University of Michigan and the editor, Eileen Crimmins, for helpful comments. 
References

Almond, D., \& Currie, J. (2011). Killing me softly: The fetal origins hypothesis. The Journal of Economic Perspectives, 25(3), 153-172.

Almond D, Mazumder B. (2005). The 1918 Influenza Pandemic and Subsequent Health Outcomes: An Analysis of SIPP Data. American Economic Review, 95, 258-262.

Almond D, Mazumder B. (2011). Health Capital and the Prenatal Environment: The Effect of Ramadan Observance During Pregnancy. American Economic Journal: Applied Economics, 3, 56-85.

Almond D, Mazumder B, Van Ewijk R (2014). In utero Ramadan exposure and children's academic performance. Economic Journal - forthcoming.

Alwasel SH, Abotalib Z, Aljarallah JS, Osmond C, Alkharaz SM, Alhazza IM, Badr G, Barker DJP. (2010) Changes in Placental Size during Ramadan. Placenta, 31, 607-610.

Banerjee A, Duflo E, Postel-Vinay G, Watts T. (2010). Long-run health impacts of income shocks: wine and phylloxera in nineteenth-century France. The Review of Economics and Statistics, 92(4), 714-728.

Barker DJP. (1995) Fetal Origins of Coronary Heart Disease. British Medical Journal, 311, 171-174.

Barker DJP. (1997), Fetal nutrition and cardiovascular disease in later life. British Medical Bulletin, 53(1) 96-108.

Barker DJP, Osmond C, Winter PD, Margetts B, Simmonds SJ. (1989) Weight in infancy and death from ischaemic heart disease. The Lancet, 334(8663), 577-580.

Chen Y, Zhou L (2007) The Long-term Health and Economic Consequences of the 1959-1961 Famine in China. Journal of Health Economics, 26:659-681.

Cohen AA, Tillinghast J, Canudas-Romo V. (2010). No consistent effects of prenatal or neonatal exposure to Spanish flu on late-life mortality in 24 developed countries. Demographic research, 22(20), 579634.

Cotter D, Pariante CM. (2002) Stress and the progression of the developmental hypothesis of schizophrenia. British Journal of Psychiatry, 181, 363-365

Cutler DM, Miller G, Norton DM. (2007). Evidence on early-life income and late-life health from America's Dust Bowl era. Proceedings of the National Academy of Sciences, 104(33), 13244-13249.

Davey Smith G. (2005). Epidemiological Freudianism. International Journal of Epidemiology, 34, 1-2.

De Rooij SR, Wouters H, Yonker JE, Painter RC, Roseboom TJ. (2010). Prenatal undernutrition and cognitive function in late adulthood. Proceedings of the National Academy of Sciences, 107, 16881-16886

Dehejia R, Lleras-Muney A (2004), Booms, Busts and Babies Health, Quarterly Journal of Economics, 119:1091-1130.

Egle M. (1943) Wesen und Formen der Verbrauchsrationierung in Europa. Weltwirtschaftliches Archiv, 58(2), 305-334. 
Godfrey KM, Barker DJP. (2001), Fetal Programming and Adult Health, Public Health Nutrition, 4(2B), 611624.

Hermann TS, Siega-Riz AM, Hobel CJ, Aurora C, Dunkel-Schetter C. (2001), Prolonged periods without food intake during pregnancy increase risk for elevated maternal corticotropin-releasing hormone concentrations, Am J Obstet Gynecol, 185(2) 403-412.

Hobel CJ, Culhane J. (2003), Role of Psychosocial and Nutritional Stress on Poor Pregnancy Outcome, The Journal of Nutrition, 133, 1709S-1717S, Supplement: Nutrition as a Preventive Strategy against Adverse Pregnancy Outcomes.

Human Mortality Database. University of California, Berkeley (USA), and Max Planck Institute for Demographic Research (Germany). Available at www.mortality.org or www.humanmortality.de (data downloaded on Oct. 31, 2013).

Jurges H. (2011). Collateral damage: Educational attainment and labor market outcomes among German war and post-war cohorts. Working paper, University of Wuppertal.

Kapoor A, Dunn E, Kostaki A, Andrews M, Matthews S. (2006). Fetal programming of hypothalamopituitary-adrenal function: prenatal stress and glucocorticoids. The Journal of Physiology 572(1), 31-44.

Kuh D, Shlomo YB. (Eds.). (2004). A life course approach to chronic disease epidemiology (Vol. 2). Oxford University Press.

Lindeboom M, Portrait F, Van den Berg GJ. (2010), Long-run Effects on Longevity of a Nutritional Shock Early in Life: The Dutch Potato Famine of 1846-1847, Journal of Health Economics, 29(5), 617-629. Lindeboom M, Van Ewijk R (2013), Early life conditions and later life inequality in health. In: Rosa Dias P, O'Donnell O (ed.) Health and Inequality (Research on Economic Inequality, Volume 21), Emerald Group Publishing Limited: 399-419.

Lopuhaä CE, Roseboom TJ, Osmond C, Barker DJP, Ravelli AC, Bleker OP, Van der Zee JS, Van der Meulen $\mathrm{JH}$. (2000) Atopy, lung function, and obstructive airways disease after prenatal exposure to famine. Thorax, 55, 555-561.

Lumey LH, Stein AD, Susser E. (2011) Prenatal Famine and Adult Health, Annual Review of Public Health, $32,24.1-24.26$.

Malhotra A, Scott PH, Scott J, Gee H, Wharton BA. (1989), Metabolic changes in Asian Muslim pregnant mothers observing the Ramadan fast in Britain. British Journal of Nutrition, 61, 663-672.

Meng X, Qian N. (2009). The long-run consequences of famine on survivors: evidence from a unique natural experiment using China's Great Famine, NBER Working Paper 14917.

Metzger BE, Ravnikas V, Vileisis RA, Norbert F. (1982), "Accelerated starvation" and the skipped breakfast in late normal pregnancy. The Lancet, 1(8272), 588-592. 
Mirghani HM, Weerasinghe SD, Smith JR, Ezimokhai M. (2004), The effect of intermittent maternal fasting on human fetal breathing movements, Journal of Obstetrics and Gynaecology, 24(6),635-637.

Mirghani HM, Weerasinghe SD, Al-Awar S, Abdulla L, Ezimokhai M. (2005), The Effect of Intermittent Maternal Fasting on Computerized Fetal Heart Tracing, Journal of Perinatology, 25, 90-92.

Mouré K. (2010) Food Rationing and the Black Market in France (1940-1944). French history, 24(2), $262-$ 282.

Myrskylä, M. (2010). The effects of shocks in early life mortality on later life expectancy and mortality compression: A cohort analysis. Demographic Research, 22(12), 289-320.

Neelsen S, Stratmann T. (2011). Effects of prenatal and early life malnutrition: Evidence from the Greek famine, Journal of Health Economics 30(3): pp. 479-488.

Painter RC, Roseboom TJ, Bossuyt PM, Osmond C, Barker DJ, Bleker OP. 2005. Adult mortality at age 57 after prenatal exposure to the Dutch famine. Eur. J. Epidemiol. 20:673-76

Prentice AM, Prentice A, Lamb WH, Lunn PG, Austin S. (1983), Metabolic consequences of fasting during Ramadan in pregnant and lactating women. Hum. Nutr. Clin. Nutr., 37C, 283-294.

Roseboom TJ, Van der Meulen JH, Osmond C, Barker D J, Ravelli AC, Schroeder-Tanka JM, Van Montfrans GA, Michels RP, Bleker OP. (2000a) Coronary heart disease after prenatal exposure to the Dutch famine, 1944-45. Heart, 84, 595-598.

Roseboom TJ, Van der Meulen JH, Osmond C, Barker DJP, Ravelli AC, Bleker OP. (2000b) Plasma lipid profiles in adults after prenatal exposure to the Dutch famine. The American Journal of Clinical Nutrition, 72, 1101-1106.

Roseboom T J, Painter RC, Van Abeelen AF, Veenendaal MV, De Rooij SR. (2011). Hungry in the womb: what are the consequences? Lessons from the Dutch famine. Maturitas, 70(2), 141-145.

Scholte R, Van den Berg GJ, Lindeboom M. (2012). Long-run effects of gestation during the Dutch hunger winter famine on labor market and hospitalization outcomes. IZA Discussion Paper No. 6307, Bonn, Germany.

Seckl JR, Holmes MC. (2007), Mechanisms of Disease: glucocorticoids, their placental metabolism and fetal 'programming' of adult pathophysiology, Nat Clin Pract Endocrinol Metab, 3, 479-488.

Song S. 2009. Does famine have a long-term effect on cohort mortality? Evidence from the 1959-1961 Great Leap Forward famine in China. J. Biosoc. Sci. 41:469-91

St. Clair D, Xu M, Wang P, Yu Y, Fang Y, et al. (2005) Rates of adult schizophrenia following prenatal exposure to the Chinese famine of 1959-1961. JAMA, 294, 557-562

Vaiserman A, Lumey LH (eds) (2013), Early Life Nutrition and Adult Health and Development, Nova Science publishers 
Van den Berg GJ, Doblhammer G, Christensen K. (2011), Being born under adverse economic conditions leads to a higher cardiovascular mortality rate later in life: evidence based on individuals born at different stages of the business cycle, Demography, 48(2), 507-530.

Van den Bergh BR, Mulder EJ, Mennes M \& Glover V (2005), Antenatal maternal anxiety and stress and the neurobehavioural development of the fetus and child: links and possible mechanisms. A review. Neurosci Biobehav Rev 29, 237-258.

Van Ewijk R. (2011) Long-term health effects on the next generation of Ramadan fasting during pregnancy. Journal of Health Economics, 30, 1246-1260.

Van Ewijk R, Painter RC, Roseboom TJ. (2013) Associations of prenatal exposure to Ramadan with small stature and thinness in adulthood: results from a large Indonesian population-based study. American Journal of Epidemiology, 177, 729-736.

Van Os J, Selten JP. (1998) Prenatal exposure to maternal stress and subsequent schizophrenia: the May 1940 invasion of the Netherlands. British Journal of Psychiatry, 172, 324-326

Yeung GY, Van den Berg GJ, Lindeboom M, Portrait F. (2014) The impact of early life economic conditions on cause-specific mortality during adulthood, Journal of Population Economics, 27(3), 895-919. 
Figure 1: Female life expectancy at birth by year
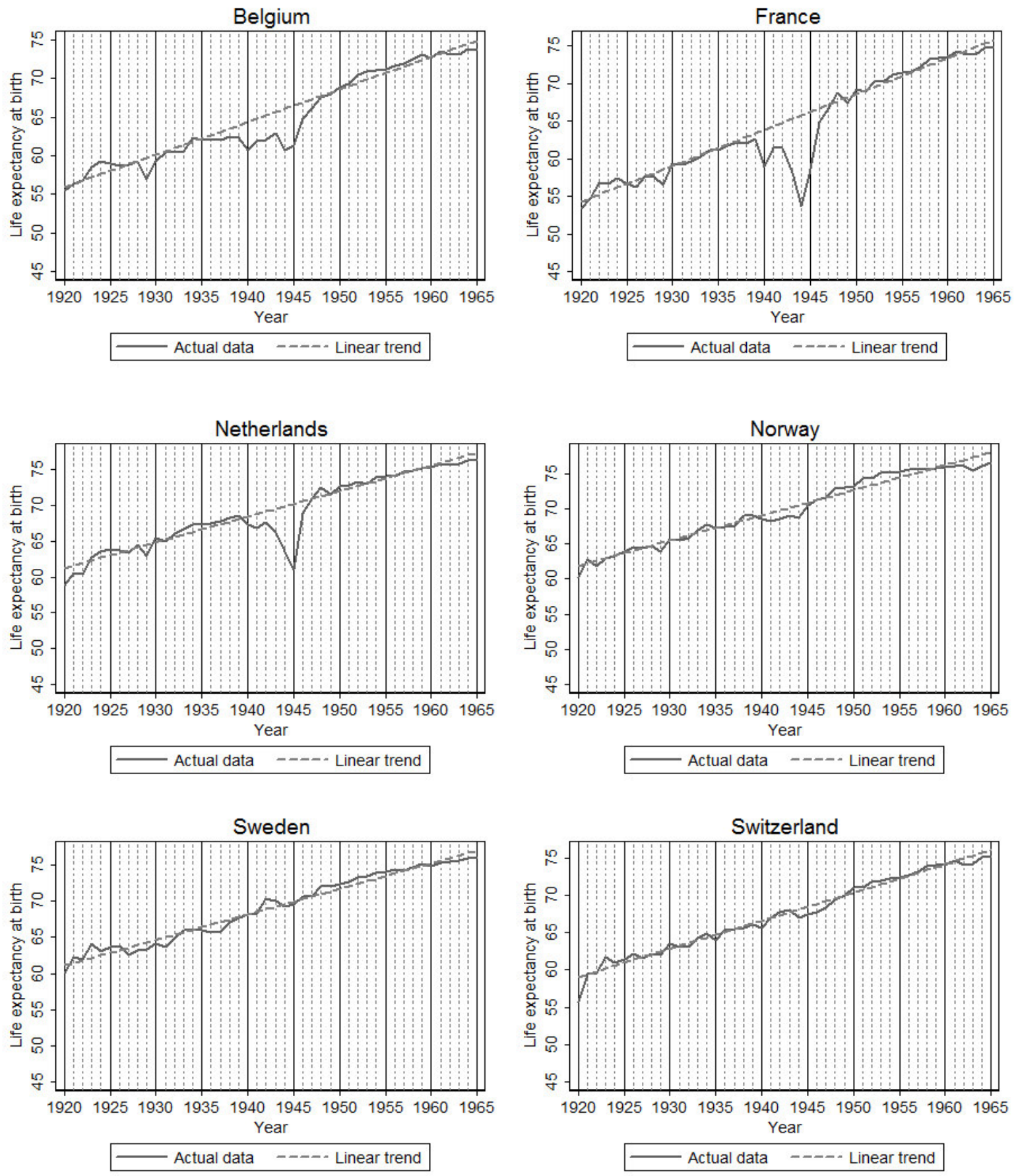
Figure 2: Probabilty of surviving to age 55: females
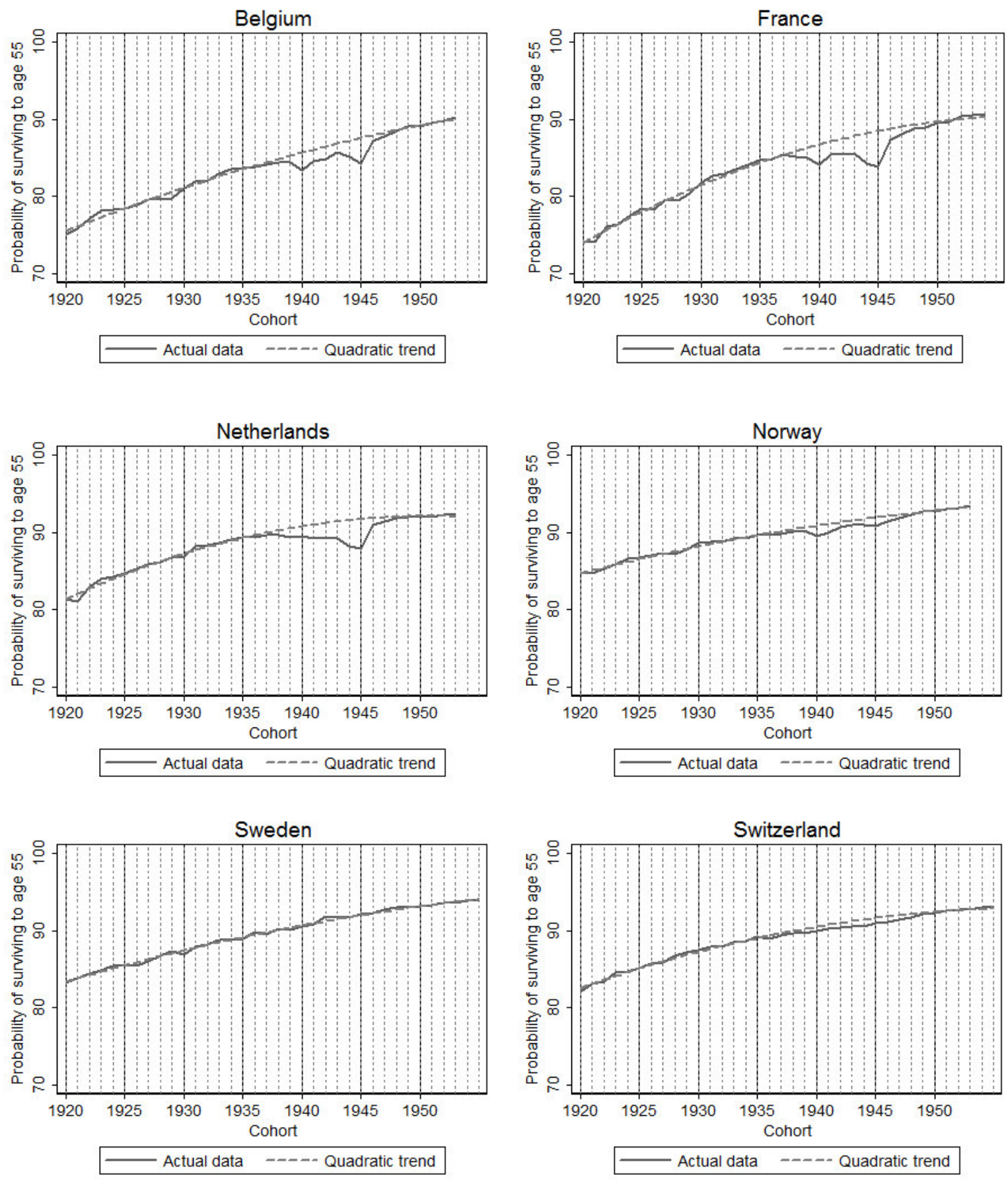
Figure 3: Probabilty of surviving to age 55 conditional on reaching age 1: females
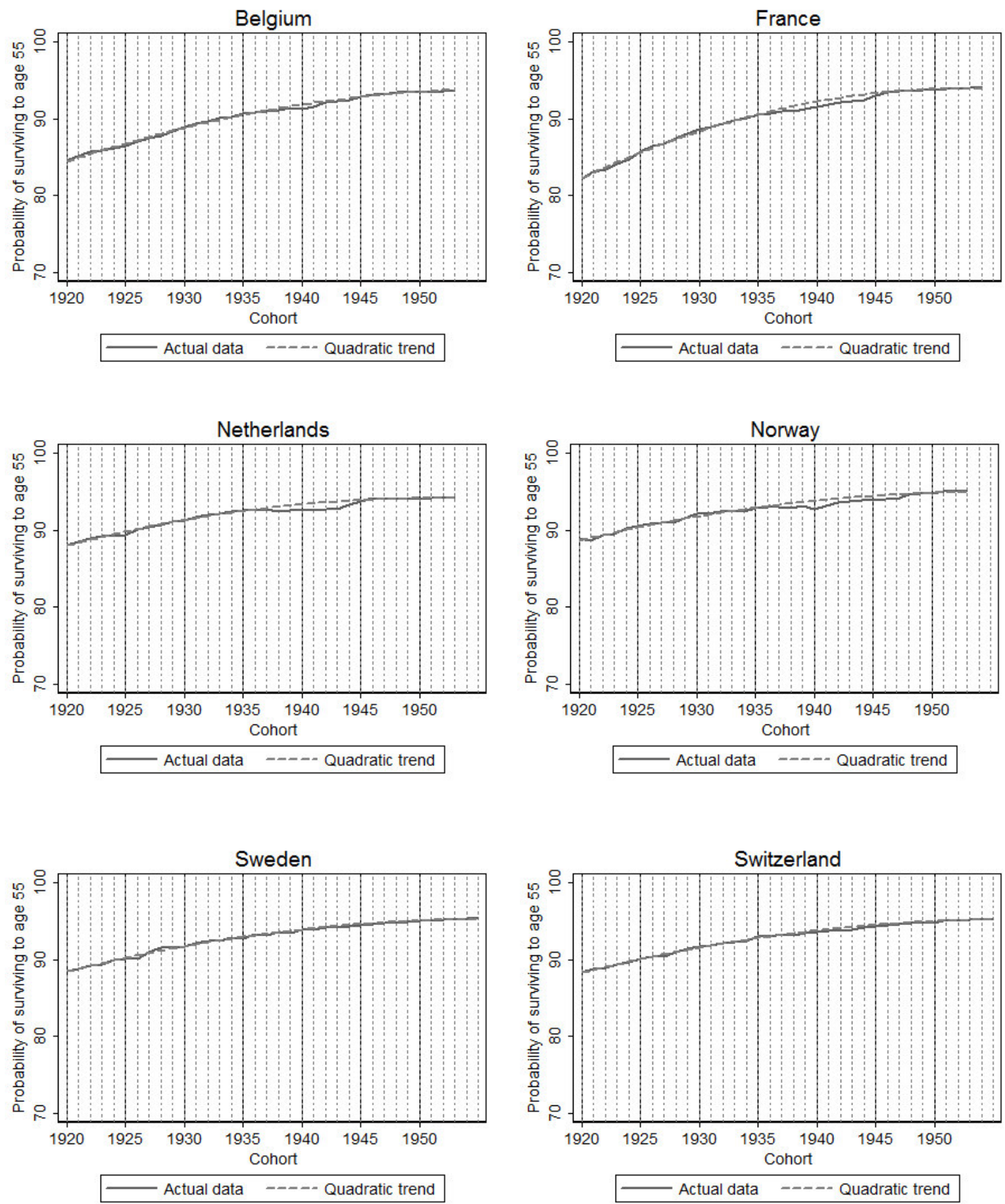
Figure 4: Probabilty of surviving to age 55 conditional on reaching age 5: females
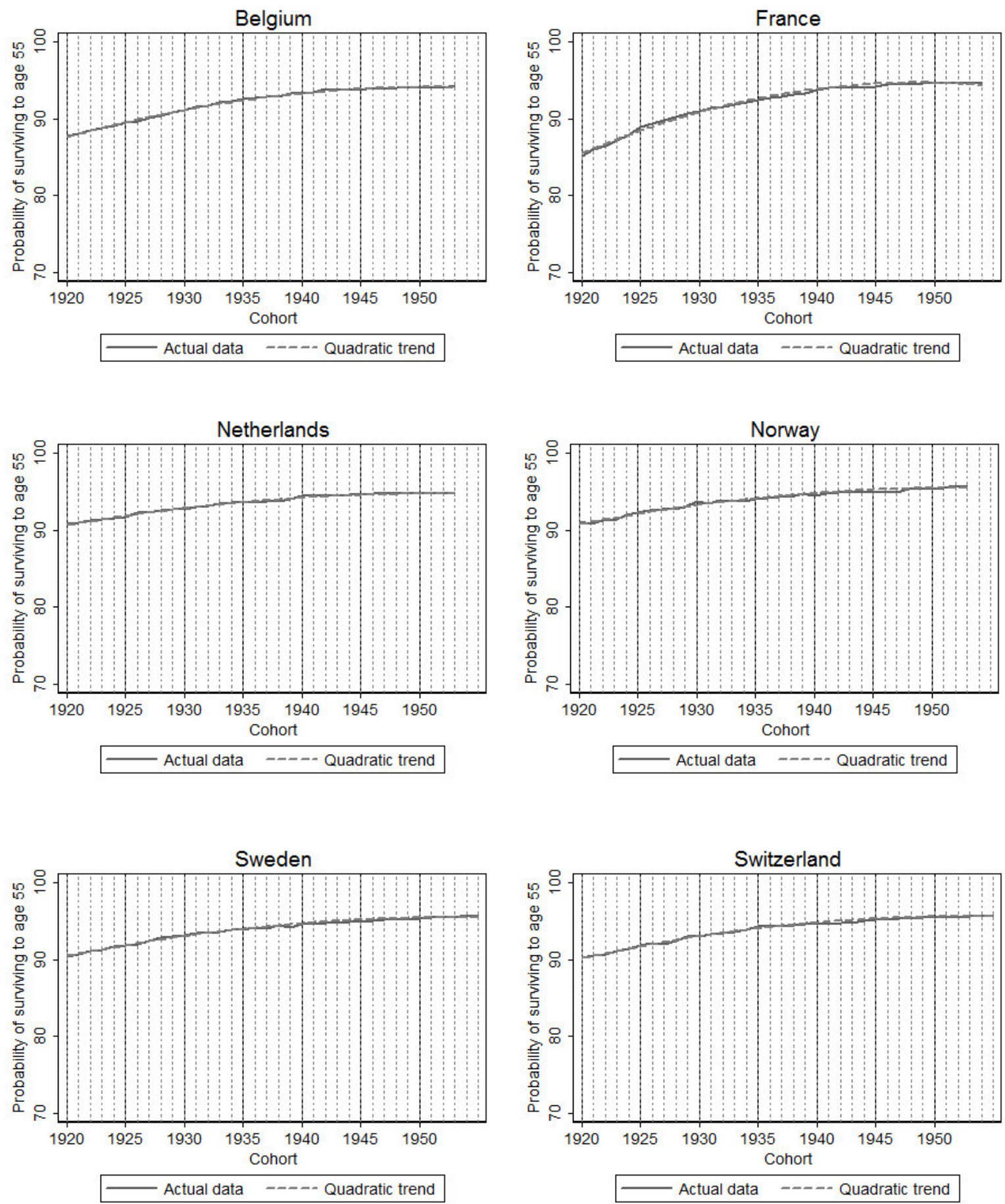
Figure 5: Probabilty of surviving to age 55: males
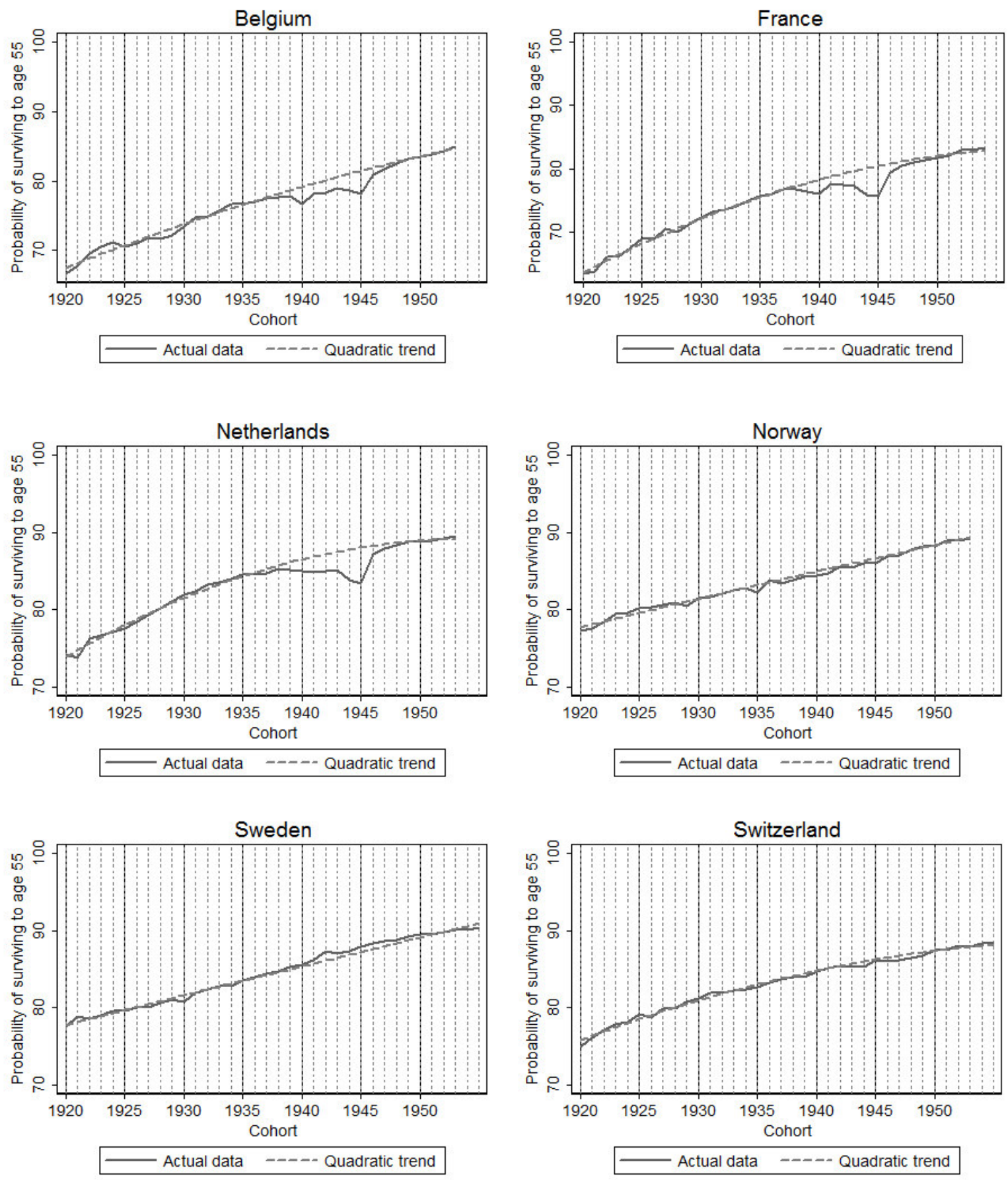
Figure 6: Probabilty of surviving to age 55 conditional on reaching age 1: males
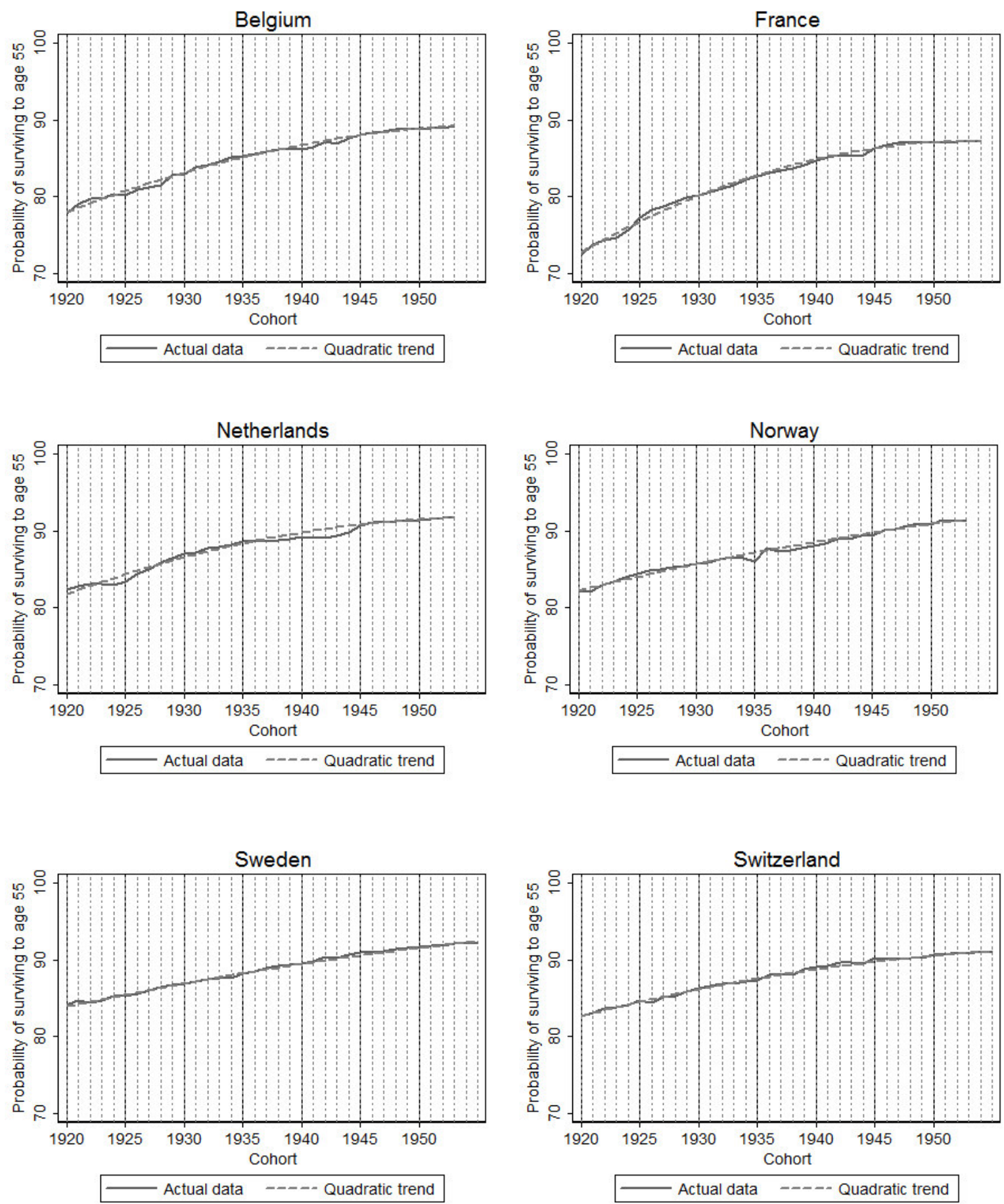
Figure 7: Probabilty of surviving to age 55 conditional on reaching age 5: males
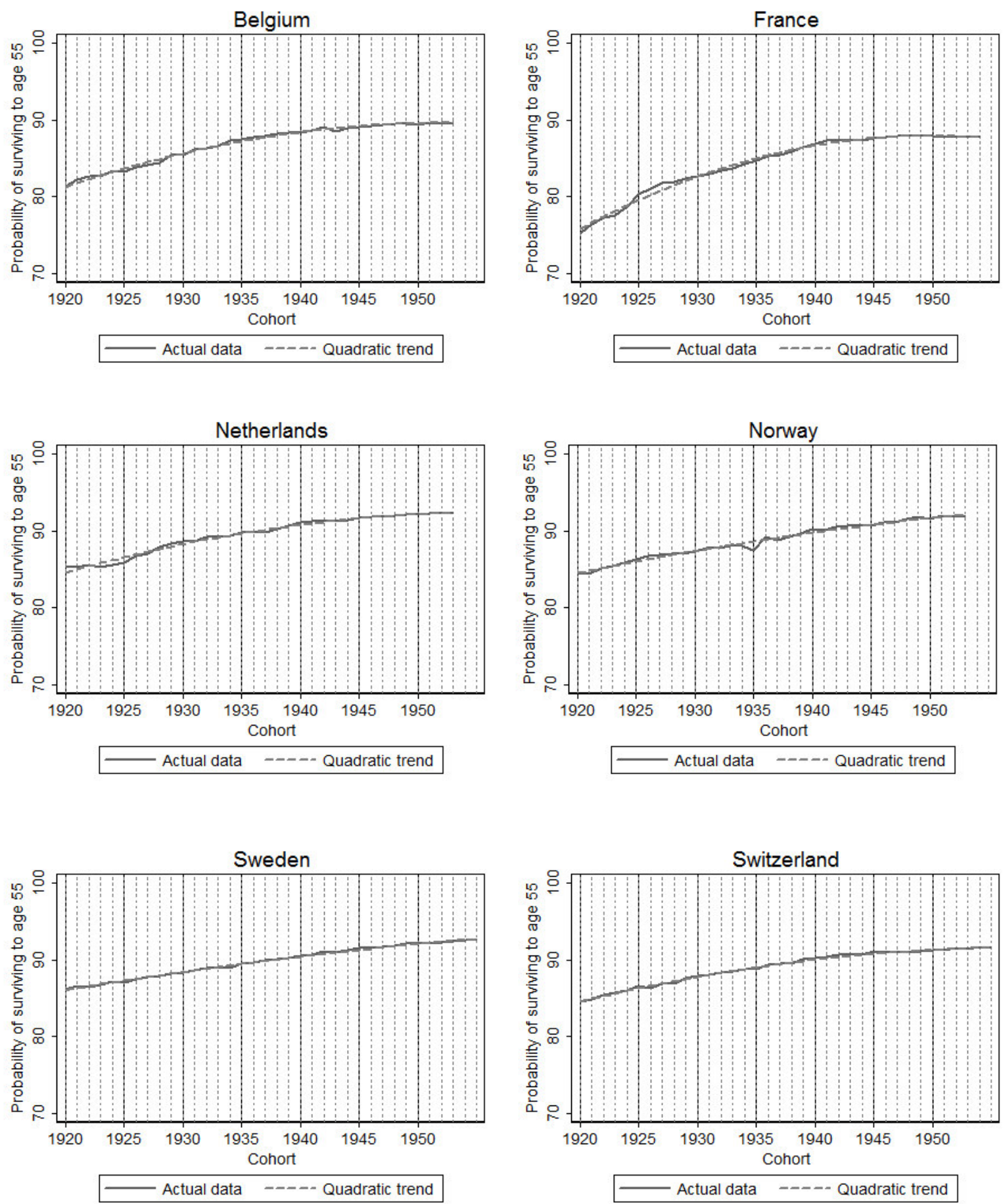
Table 1: Deviations from linear trend in female life expectancy at birth by country \& year

\begin{tabular}{lrrrrrr}
\hline & Belgium & France & Netherlands & Norway & Sweden & Switzerland \\
\hline 1940 & $-3.60^{* *}$ & $-4.88^{* *}$ & -1.13 & -0.46 & -0.07 & -0.90 \\
& $(0.90)$ & $(0.75)$ & $(0.82)$ & $(0.85)$ & $(0.79)$ & $(0.80)$ \\
1941 & $-2.86^{* *}$ & $-2.85^{* *}$ & $-1.90^{*}$ & -1.17 & -0.21 & 0.07 \\
& $(0.90)$ & $(0.75)$ & $(0.82)$ & $(0.85)$ & $(0.79)$ & $(0.80)$ \\
1942 & $-3.16^{* *}$ & $-3.34^{* *}$ & $-1.50+$ & -1.17 & $1.47+$ & 0.42 \\
& $(0.90)$ & $(0.75)$ & $(0.82)$ & $(0.85)$ & $(0.79)$ & $(0.80)$ \\
1943 & $-2.62^{* *}$ & $-7.14^{* *}$ & $-3.27^{* *}$ & -1.11 & 0.85 & 0.29 \\
& $(0.90)$ & $(0.75)$ & $(0.82)$ & $(0.85)$ & $(0.79)$ & $(0.80)$ \\
1944 & $-5.26^{* *}$ & $-12.06^{* *}$ & $-6.26^{* *}$ & $-1.83^{*}$ & -0.30 & -1.05 \\
& $(0.90)$ & $(0.75)$ & $(0.82)$ & $(0.85)$ & $(0.79)$ & $(0.80)$ \\
1945 & $-5.11^{* *}$ & $-7.62^{* *}$ & $-9.15^{* *}$ & -0.42 & -0.43 & -1.08 \\
& $(0.90)$ & $(0.75)$ & $(0.82)$ & $(0.85)$ & $(0.79)$ & $(0.80)$ \\
1946 & $-2.03^{*}$ & $-1.74^{*}$ & $-1.64+$ & 0.04 & 0.36 & -1.07 \\
& $(0.90)$ & $(0.75)$ & $(0.82)$ & $(0.85)$ & $(0.79)$ & $(0.80)$ \\
1947 & -1.09 & -0.53 & -0.10 & 0.09 & -0.05 & -0.88 \\
& $(0.90)$ & $(0.75)$ & $(0.82)$ & $(0.85)$ & $(0.79)$ & $(0.80)$ \\
\multirow{4}{*}{ Birth year } & $0.42^{* *}$ & $0.48^{* *}$ & $0.36^{* *}$ & $0.36^{* *}$ & $0.35^{* *}$ & $0.38^{* *}$ \\
& $(0.01)$ & $(0.01)$ & $(0.01)$ & $(0.01)$ & $(0.01)$ & $(0.01)$ \\
\hline
\end{tabular}

Each column shows the results from an ordinary least squares regression of female life expectancy at birth on birth cohort and eight dummy variables indicating specific birth years.

Sample: cohorts born between 1920 and 1965. Data: Human Mortality Database.

$+p<0.10,{ }^{*} p<0.05,{ }^{* *} p<0.01$ 
Table 2: Females: Probability to survive to age 55

\begin{tabular}{|c|c|c|c|c|c|c|c|c|c|c|c|c|c|c|c|c|c|c|}
\hline & \multicolumn{3}{|c|}{ Belgium } & \multicolumn{3}{|c|}{ France } & \multicolumn{3}{|c|}{ Netherlands } & \multicolumn{3}{|c|}{ Norway } & \multicolumn{3}{|c|}{ Sweden } & \multicolumn{3}{|c|}{ Switzerland } \\
\hline reaching age: & 0 & 1 & 5 & 0 & 1 & 5 & 0 & 1 & 5 & 0 & 1 & 5 & 0 & 1 & 5 & 0 & 1 & 5 \\
\hline 1938 & $\begin{array}{r}-0.50 \\
(0.41)\end{array}$ & $\begin{array}{r}-0.30 \\
(0.19)\end{array}$ & $\begin{array}{r}-0.08 \\
(0.11)\end{array}$ & $\begin{array}{r}-0.74 \\
(0.44)\end{array}$ & $\begin{array}{r}-0.60 * * \\
(0.19)\end{array}$ & $\begin{array}{r}-0.32 \\
(0.26)\end{array}$ & $\begin{array}{r}-0.66+ \\
(0.33)\end{array}$ & $\begin{array}{r}-0.56 * * \\
(0.17)\end{array}$ & $\begin{array}{l}-0.20 * \\
(0.08)\end{array}$ & $\begin{array}{r}-0.33 \\
(0.24)\end{array}$ & $\begin{array}{r}-0.65^{* *} \\
(0.21)\end{array}$ & $\begin{array}{r}-0.28 \\
(0.20)\end{array}$ & $\begin{array}{r}0.17 \\
(0.23)\end{array}$ & $\begin{array}{r}0.09 \\
(0.18)\end{array}$ & $\begin{array}{r}-0.01 \\
(0.15)\end{array}$ & $\begin{array}{r}-0.38 \\
(0.27)\end{array}$ & $\begin{array}{r}-0.22 \\
(0.14)\end{array}$ & $\begin{array}{r}-0.07 \\
(0.12)\end{array}$ \\
\hline 1939 & $\begin{array}{c}-0.86 * \\
(0.41)\end{array}$ & $\begin{array}{r}-0.23 \\
(0.19)\end{array}$ & $\begin{array}{r}0.06 \\
(0.11)\end{array}$ & $\begin{array}{r}-1.39 * * \\
(0.44)\end{array}$ & $\begin{array}{r}-0.69 * * \\
(0.19)\end{array}$ & $\begin{array}{r}-0.31 \\
(0.26)\end{array}$ & $\begin{array}{r}-1.13^{* *} \\
(0.33)\end{array}$ & $\begin{array}{r}-0.66^{* *} \\
(0.17)\end{array}$ & $\begin{array}{r}-0.07 \\
(0.08)\end{array}$ & $\begin{array}{r}-0.31 \\
(0.24)\end{array}$ & $\begin{array}{c}-0.46^{*} \\
(0.21)\end{array}$ & $\begin{array}{r}0.09 \\
(0.20)\end{array}$ & $\begin{array}{r}-0.23 \\
(0.23)\end{array}$ & $\begin{array}{r}-0.34+ \\
(0.18)\end{array}$ & $\begin{array}{c}-0.37 * \\
(0.15)\end{array}$ & $\begin{array}{l}-0.59 * \\
(0.27)\end{array}$ & $\begin{array}{r}-0.22 \\
(0.14)\end{array}$ & $\begin{array}{c}-0.14 \\
(0.12)\end{array}$ \\
\hline 1940 & $\begin{array}{r}-2.29 * * \\
(0.41)\end{array}$ & $\begin{array}{r}-0.66^{* *} \\
(0.19)\end{array}$ & $\begin{array}{r}-0.06 \\
(0.11)\end{array}$ & $\begin{array}{r}-2.64 * * \\
(0.44)\end{array}$ & $\begin{array}{r}-0.66^{* *} \\
(0.19)\end{array}$ & $\begin{array}{r}-0.12 \\
(0.26)\end{array}$ & $\begin{array}{r}-1.34 * * \\
(0.33)\end{array}$ & $\begin{array}{r}-0.59 * * \\
(0.17)\end{array}$ & $\begin{array}{l}0.33 * * \\
(0.08)\end{array}$ & $\begin{array}{r}-1.28 * * \\
(0.24)\end{array}$ & $\begin{array}{r}-1.13^{* *} \\
(0.21)\end{array}$ & $\begin{array}{r}-0.34 \\
(0.20)\end{array}$ & $\begin{array}{r}-0.08 \\
(0.23)\end{array}$ & $\begin{array}{r}-0.06 \\
(0.18)\end{array}$ & $\begin{array}{r}-0.07 \\
(0.15)\end{array}$ & $\begin{array}{r}-0.55+ \\
(0.27)\end{array}$ & $\begin{array}{r}-0.24+ \\
(0.14)\end{array}$ & $\begin{array}{r}-0.16 \\
(0.12)\end{array}$ \\
\hline 1941 & $\begin{array}{r}-1.45^{* *} \\
(0.41)\end{array}$ & $\begin{array}{r}-0.58 * * \\
(0.19)\end{array}$ & $\begin{array}{r}-0.02 \\
(0.11)\end{array}$ & $\begin{array}{r}-1.68 * * \\
(0.44)\end{array}$ & $\begin{array}{r}-0.57^{* *} \\
(0.19)\end{array}$ & $\begin{array}{r}-0.04 \\
(0.26)\end{array}$ & $\begin{array}{r}-1.84 * * \\
(0.33)\end{array}$ & $\begin{array}{r}-0.99 * * \\
(0.16)\end{array}$ & $\begin{array}{r}0.11 \\
(0.08)\end{array}$ & $\begin{array}{r}-1.16 * * \\
(0.24)\end{array}$ & $\begin{array}{r}-0.85^{* *} \\
(0.21)\end{array}$ & $\begin{array}{r}-0.18 \\
(0.20)\end{array}$ & $\begin{array}{r}-0.16 \\
(0.23)\end{array}$ & $\begin{array}{r}-0.20 \\
(0.18)\end{array}$ & $\begin{array}{r}-0.19 \\
(0.15)\end{array}$ & $\begin{array}{r}-0.50+ \\
(0.27)\end{array}$ & $\begin{array}{r}-0.20 \\
(0.14)\end{array}$ & $\begin{array}{c}-0.33 * \\
(0.12)\end{array}$ \\
\hline 1942 & $\begin{array}{r}-1.66 * * \\
(0.41)\end{array}$ & $\begin{array}{r}-0.17 \\
(0.19)\end{array}$ & $\begin{array}{c}0.24 * \\
(0.11)\end{array}$ & $\begin{array}{r}-2.05^{* *} \\
(0.44)\end{array}$ & $\begin{array}{r}-0.59 * * \\
(0.19)\end{array}$ & $\begin{array}{r}-0.20 \\
(0.26)\end{array}$ & $\begin{array}{r}-1.86 * * \\
(0.33)\end{array}$ & $\begin{array}{r}-0.95 * * \\
(0.16)\end{array}$ & $\begin{array}{l}0.23 * * \\
(0.08)\end{array}$ & $\begin{array}{r}-0.69 * * \\
(0.24)\end{array}$ & $\begin{array}{l}-0.54 * \\
(0.21)\end{array}$ & $\begin{array}{r}-0.15 \\
(0.20)\end{array}$ & $\begin{array}{r}0.65 * \\
(0.23)\end{array}$ & $\begin{array}{r}-0.05 \\
(0.18)\end{array}$ & $\begin{array}{r}-0.13 \\
(0.15)\end{array}$ & $\begin{array}{r}-0.54+ \\
(0.27)\end{array}$ & $\begin{array}{c}-0.33^{*} \\
(0.14)\end{array}$ & $\begin{array}{c}-0.27^{*} \\
(0.12)\end{array}$ \\
\hline 1943 & $\begin{array}{c}-1.14 * \\
(0.41)\end{array}$ & $\begin{array}{r}-0.28 \\
(0.19)\end{array}$ & $\begin{array}{r}0.01 \\
(0.11)\end{array}$ & $\begin{array}{r}-2.24 * * \\
(0.44)\end{array}$ & $\begin{array}{r}-0.69 * * \\
(0.19)\end{array}$ & $\begin{array}{r}-0.30 \\
(0.26)\end{array}$ & $\begin{array}{r}-2.14^{* *} \\
(0.33)\end{array}$ & $\begin{array}{r}-0.96 * * \\
(0.16)\end{array}$ & $\begin{array}{r}0.06 \\
(0.08)\end{array}$ & $\begin{array}{c}-0.62 * \\
(0.24)\end{array}$ & $\begin{array}{l}-0.50 * \\
(0.21)\end{array}$ & $\begin{array}{r}-0.18 \\
(0.20)\end{array}$ & $\begin{array}{r}0.17 \\
(0.23)\end{array}$ & $\begin{array}{r}-0.28 \\
(0.18)\end{array}$ & $\begin{array}{r}-0.30+ \\
(0.15)\end{array}$ & $\begin{array}{c}-0.71 * \\
(0.27)\end{array}$ & $\begin{array}{r}-0.42 * * \\
(0.14)\end{array}$ & $\begin{array}{r}-0.36 * * \\
(0.12)\end{array}$ \\
\hline 1944 & $\begin{array}{r}-2.11^{* *} \\
(0.40)\end{array}$ & $\begin{array}{r}-0.25 \\
(0.19)\end{array}$ & $\begin{array}{r}-0.11 \\
(0.11)\end{array}$ & $\begin{array}{r}-3.92 * * \\
(0.44)\end{array}$ & $\begin{array}{r}-0.79 * * \\
(0.19)\end{array}$ & $\begin{array}{r}-0.38 \\
(0.26)\end{array}$ & $\begin{array}{r}-3.35 * * \\
(0.33)\end{array}$ & $\begin{array}{r}-0.59 * * \\
(0.16)\end{array}$ & $\begin{array}{r}0.13 \\
(0.08)\end{array}$ & $\begin{array}{r}-0.80 * * \\
(0.24)\end{array}$ & $\begin{array}{l}-0.52 * \\
(0.21)\end{array}$ & $\begin{array}{r}-0.25 \\
(0.20)\end{array}$ & $\begin{array}{r}-0.03 \\
(0.23)\end{array}$ & $\begin{array}{r}-0.13 \\
(0.18)\end{array}$ & $\begin{array}{r}-0.16 \\
(0.15)\end{array}$ & $\begin{array}{r}-0.83 * * \\
(0.27)\end{array}$ & $\begin{array}{r}-0.23 \\
(0.14)\end{array}$ & $\begin{array}{r}-0.21 \\
(0.12)\end{array}$ \\
\hline 1946 & $\begin{array}{r}-0.69 \\
(0.40)\end{array}$ & $\begin{array}{r}0.19 \\
(0.19)\end{array}$ & $\begin{array}{r}0.04 \\
(0.11)\end{array}$ & $\begin{array}{r}-1.52^{* *} \\
(0.43)\end{array}$ & $\begin{array}{r}-0.03 \\
(0.19)\end{array}$ & $\begin{array}{r}-0.23 \\
(0.26)\end{array}$ & $\begin{array}{c}-0.85 * \\
(0.33)\end{array}$ & $\begin{array}{r}0.14 \\
(0.16)\end{array}$ & $\begin{array}{r}0.13 \\
(0.08)\end{array}$ & $\begin{array}{r}-0.67 * * \\
(0.24)\end{array}$ & $\begin{array}{c}-0.56 * \\
(0.20)\end{array}$ & $\begin{array}{r}-0.41+ \\
(0.20)\end{array}$ & $\begin{array}{r}0.01 \\
(0.23)\end{array}$ & $\begin{array}{r}-0.20 \\
(0.18)\end{array}$ & $\begin{array}{r}-0.28+ \\
(0.15)\end{array}$ & $\begin{array}{c}-0.65 * \\
(0.27)\end{array}$ & $\begin{array}{r}-0.11 \\
(0.14)\end{array}$ & $\begin{array}{r}-0.17 \\
(0.12)\end{array}$ \\
\hline 1947 & $\begin{array}{r}-0.52 \\
(0.40)\end{array}$ & $\begin{array}{r}0.01 \\
(0.19)\end{array}$ & $\begin{array}{r}-0.06 \\
(0.11)\end{array}$ & $\begin{array}{l}-0.96 * \\
(0.43)\end{array}$ & $\begin{array}{r}0.02 \\
(0.19)\end{array}$ & $\begin{array}{r}-0.16 \\
(0.26)\end{array}$ & $\begin{array}{r}-0.49 \\
(0.33)\end{array}$ & $\begin{array}{r}0.04 \\
(0.16)\end{array}$ & $\begin{array}{r}0.06 \\
(0.08)\end{array}$ & $\begin{array}{r}-0.46+ \\
(0.24)\end{array}$ & $\begin{array}{l}-0.56^{*} \\
(0.21)\end{array}$ & $\begin{array}{l}-0.51^{*} \\
(0.20)\end{array}$ & $\begin{array}{r}0.25 \\
(0.23)\end{array}$ & $\begin{array}{r}-0.04 \\
(0.17)\end{array}$ & $\begin{array}{r}-0.15 \\
(0.15)\end{array}$ & $\begin{array}{l}-0.58 * \\
(0.27)\end{array}$ & $\begin{array}{r}-0.18 \\
(0.14)\end{array}$ & $\begin{array}{r}-0.18 \\
(0.12)\end{array}$ \\
\hline
\end{tabular}

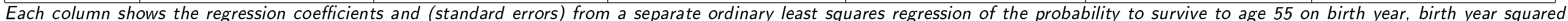
and eight dummies indicating birth in 1938...1947. The sample in each regression is limited to those people surviving to at least age $0 / 1 / 5$.

$+p<0.10,{ }^{*} p<0.05,{ }^{* *} p<0.01$

Sample: cohorts born between 1920 and 1965. Data: Human Mortality Database. 
Table 3: Males: Probability to survive to age 55

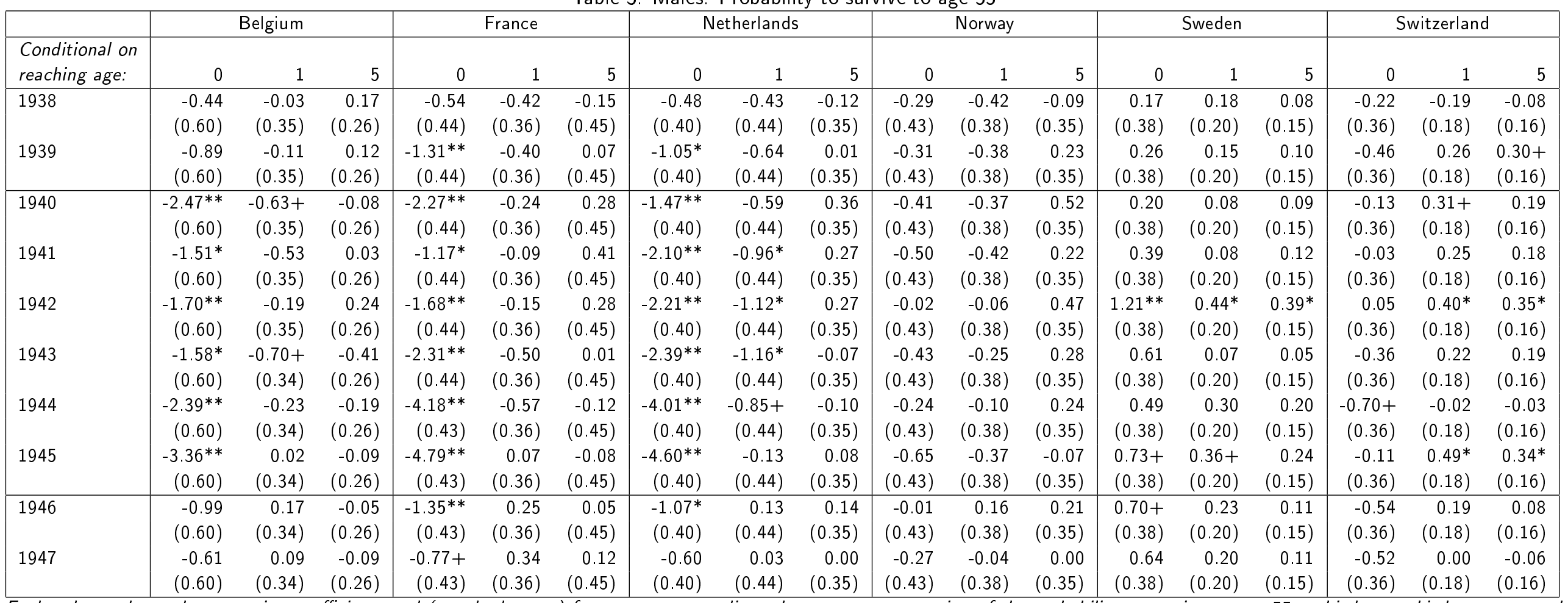

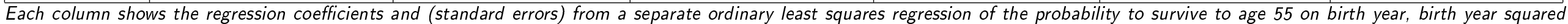
and eight dummies indicating birth in 1938...1947. The sample in each regression is limited to those people surviving to at least age $0 / 1 / 5$.

$+p<0.10,{ }^{*} p<0.05,{ }^{* *} p<0.01$

Sample: cohorts born between 1920 and 1965. Data: Human Mortality Database. 